\title{
ВОПРОСЫ МЕЖДУНАРОДНОГО И ЕВРОПЕЙСКОГО ПРАВА
}

\section{Недропользование: некоторые теоретические вопросы международного права}

\section{Вылегжанин A.H.*}

Международное право в XXI веке, являясь само по себе фактором глобализации, одновременно испытывает ее воздействие: верховенство международного права как цель миропорядка становится общепризнанным; востребована целостность правотворчества и правоприменения, противополагаемая фрагментарности международного права; международно-правовое регулирование становится все более комплексным при сочетающемся осуществлении международного публичного и международного частного права; возрастает взаимодействие права международного и национального; юстиция в современном мире все более интернационализуется, при этом усиливается роль Международного Суда $\mathrm{OOH}^{1}$.

Обозначенные тенденции развития современного международного права проявляются и в тех его отраслях, подотраслях, институтах и нормах, которые применимы к регулированию международных отношений, возникающих в связи с природопользованием вообще и с использованием недр, энергетических природных ресурсов в частности.

Уже отмечено, что нефть, газ, уголь, руды, иные залегающие в недрах минеральные ресурсы, на которых знждется энергетика, - это

\footnotetext{
- Вылегжанин Александр Николаевич - д.ю.н., проф. МГИМО (У) МИД России.

${ }^{1}$ См. об этом, например: F.O. Vicuna, C. Pinto. The Peaceful Settlement of Disputes: Prospect for the Twenty-first Century. 1998. P. VII, etc; Каламкарян Р.A. Господство права в международных отношениях. М., 2004. С. 451 и далее; Колодкин Р.А. Фрагментация международного права // Московский журнал международного права. 2005. № 2. C. $38-61$.
} 
сокровища, разведанные запасы которых иссякают, а перспективы обнаружения новых и их практического вовлечения в экономический оборот достаточно неопределенны ${ }^{2}$. Неудивительно поэтому, что энергетические ресурсы, недра становятся объектом все большего числа международных правоотношений и уже повсеместно не считаются исключительно объектом национального права. Растущая взаимозависимость государств и иных субъектов международного права в связи с деятельностью в недрах отражена в универсальных договорных источниках: Женевских морских конвенчиях 1958 г., Конвенции ООН по морскому праву 1982 г., Конвенции о биологическом разнообразии 1992 г., Рамочной конвенчии ООН об изменении климата 1992 г. и др.

Эта взаимосвязь подтверждается также международно-правовыми документами регионального характера, в т.ч. разработанными с участием России: Европейской энергетической хартией 1991 г. (эту декларацию, кроме европейских государств, подписали также США, Канада, Япония); Договором к Энергетической хартии (1994г.); Протоколом к Энергетической хартии по вопросам энергетической эффективности и соответствуючим экологическим аспектам (1994 г.); Горной хартией государств - участников Содружества Независимых Государств (1997 г.); Соглашением о сотрудничестве в области изучения, разведки и использования минерально-сырьевых ресурсов (1997 г.); Соглашением о приграничном сотрудничестве в области изучения, освоения и охраны недр (2001 г.) и др.; это же подтверждается двусторонними международными договорами, заключенными государствами в связи с недропользованием.

Обзор этих договорных и иных источников позволяет составить некий перечень международно-правовых вопросов недропользования, которые, как представляется, в настояшее время целесообразно вовлекать в процесс преподавания международного права, например в качестве спецкурса (по выбору студентов):

Недра как объект международно-правового регулирования. Международно-правовое значение терминов «недра», «природные ресурсы», «минеральные ресурсы», «полезные ископаемые». Делимитация недр в горизонтальной плоскости. Подземный предел недр, составляющих часть государственной территории. Подземные пределы правомерно-

2 Аренс В.Ж., Вылегжанин А.Н. Режим минеральных ресурсов по международному праву и национапьному законодательству. Предисловие к книге: Правовой режим минеральных ресурсов. М., 2002. С. 3-20. 
го недропользования за пределами государственной территории. Международно-правовые аспекты защиты окружающей среды при недропользовании. Особенности правового режима недропользования в Арктике. Законодательство Канады и России о полярных секторах и правовое регулирование недропользования в Арктике. Международно-правовая концепция устойчивого использования Арктики. Международно-правовой режим недропользования на Шпицбергене. Проблемы толкования базовых договорно-правовых документов о статусе Каспия. Современные международно-правовые основы недропользования на Каспии. Дискуссионные вопросы толкования положений универсальных международных конвенций о континентальном шельфе. Международно-правовой режим минеральных ресурсов континентального шельфа. Международно-правовые аспекты транспортировки добытых из недр шельфа углеводородов. Международно-правовая практика в области разработки трансграничных минеральных ресурсов. Правовой режим минеральных ресурсов Антарктики. Вопросы толкования и применения Соглашения ООН 1994 г. (о международно-правовом режиме морского дна за пределами национальной юрисдикции и его pecypcax).

Из большого числа международно-правовых вопросов недропользования в настояшей статье исследуются два, представляющиеся в теоретическом плане дискуссионными: во-первых, о месте в системе международного права комплекса международно-правовых норм о недропользовании; во-вторых, о международно-правовом содержании понятия «недра», юридическом определении их подземных пределов и о значении этих международно-правовых данных для российского законодателя.

Международно-правовое регулирование недропользования и международное экономическое право. Государства вступили в договорные отношения в связи с использованием недр много десятилетий тому назад: одни правоведы указывают на договорную практику Франции по оформлению горных концессий (т.е. уступок государством на согласованных условиях частной компании или другому государству права пользования участком своих недр); другие - на первый договор между Великобританией и Венесуэлой о правах на дно и недра дна в заливе Париа; третьи - на так называемые «колониальные» горные концессии, когда большие участки недр «уступались» колонией в пользу компании под давлением государства-метрополии, а условия 
такой концессии, разумеется, были далеки от баланса интересов и равноправного согласования ${ }^{3}$. Специфика международно-правового режима морских недр в международном морском праве в целом обозначена $^{4}$. Если же рассматривать общие аспекты международно-правового регулирования недропользования как на суше, так и под поверхностью дна, то очевидно: с начала 90-х годов прошлого столетия именно такая отрасль международного права, как международное экономическое право, особенно заметно приросла «энергетическим» компонентом. Напомним, что развитые западные страны, во избежание непредсказуемой энергетической дезинтеграции после распада СССР, выдвинули идею о создании новых юридических рамок сотрудничества в области энергетики с государствами постсоветского пространства, прежде всего с Россией. По первоначальному замыслу юридическая архитектура такого сотрудничества должна была быть простой: для западных компаний-инвесторов создаются международные стандарты защиты иностранных инвестиций в энергетический сектор России; в обмен на это западные страны гарантируют поошрение таких инвестиций (со стороны их крупных нефтяных компаний) в экономику России. Требование России о сбалансированности привело к иной юридической конфигурации: согласованы обшие рамки - как для западных инвестиций в российской энергетике, прежде всего в области разработки нефтегазовых ресурсов, так и российских инвестиций в западный энергетический сектор ${ }^{5}$. В 1991 г. на такой основе была одобрена Европейская энергетическая хартия, не имеющая силы договорного источника международного права. В 1994 г. принят текст Договора к Энергетической хартии. В его преамбуле напоминается, что стороны, подписавшие в 1991 г. Заключительный документ Гаагской конференции по Европейской энергетической хартии, «обязались соблюдать цели и принципы» хартии. Договор «устанавливает правовые рамки в целях оказания содействия долгосрочному сотрудниче-

' См. подробнее: Хиггинс и Коломбос. Международное морское право / Под ред. и с иредисл. С.Б. Крылова. М. 1953; Клюкин Б.Д. Горное законодательство в странах Занадной Европы и Америки. М., 2000; Сосна С.А. Концессионные соглашения. Тсория и практика. М., 2002.

` С.., наиример: Вылегжанин А.Н. Морские природные ресурсы (международно-правовой режим). М., 2001.

' Карро Д., Жюйар К. Международное зкономическое право. Пер. с фр. В.М. Шумилова. В.П. Серебрениикова. М., 2001. С. 363-366. Горное дело и окружающая среда: инровой опыт правовой гармонизации / Под ред. В.Ж. Аренса, А.Н. Вылегжанина. M., 2000, C. 3-32. 
ству в области энергетики... в соответствии с целями и принципами Хартии» (ст. 2). Договором подтверждены известные положения обшего международного права о суверенитете и суверенных правах государств в отношении их природных ресурсов, в данном случае «энергетических» (ст. 10); обозначены правовые основы развития рынка энергетических материалов и продуктов, в том числе обязательства по уменьшению препятствий конкуренции в энергетическом секторе; меры по облегчению транзита энергетических материалов и продуктов. Транзит, по смыслу Договора, - это перемещение через территорию одного государства-участника материалов, продуктов, происходящих из территории второго государства-участника и предназначенных для третьего государства-участника либо, в некоторых случаях, для этого второго государства (п. 10 ст. 7). Предусмотрено обязательство договаривающихся сторон предоставить национальный режим транзитным энергетическим материалам и продуктам, кроме случая, когда иное предусмотрено действующим международным соглашением (п. 3 ст. 7 ).

В общем плане сформулировано в Договоре обязательство сторон принимать меры содействия транзиту энергетических материалов, продуктов «в соответствии с принципом свободы транзита, без различий в том, что касается пронсхождения, места назначения, владельца таких материалов, продуктов, без дискриминационных тарифов, основанных на таких различиях, а также без чрезмерных задержек, ограничений или сборов» (п. 1 ст. 7). Предусмотрены обязательства по поощрению притока капитала в энергетический сектор, «особенно государств-участников, экономика которых находится на переходном этапе». Договор к Энергетической хартии предусматривает обязательства его участников сводить к минимуму вредное воздействие энергетики на окружающую среду. Предусмотрена преимущественная сила норм Генерального соглашения по тарифам и торговле (ГАТТ) над нормами о торговле, содержащимися в Договоре к Энергетической хартии; однако если хотя бы один участник правоотношения не является участником Соглашения о Всемирной торговой организации (ГАТТ, напомним, является одним из приложений группы 1 А к этому Соглашению), то применяются положения Договора к Энергетической хартии.

Содержание Договора показывает, что его участники не предусмотрели конкретных обязательств по либерализации доступа инвестиций в энергетический сектор: по ст. 10 каждая договариваюшаяся сторона 
«стремится» предоставить инвесторам других договаривающихся сторон некоторые преимушества; предусмотрены переговоры по заключению дополнительного договора о таких преимуществах; предусмотрена возможность предоставления в одностороннем порядке каждой договаривающейся стороной инвесторам другой стороны преимушественных режимов (национального или наибольшего благоприятствования). Вопрос о ликвидации инвестиций рассматривается в Договоре в связи с вопросом о трансфертах: «Каждая Договариваюшаяся Сторона в том, что касается инвестиций, осуществляемых... инвесторами другой Договаривающейся Стороны, гарантирует свободу трансфертов..., ...продукта продажи или ликвидации всех или части инвестиций». Участниками Договора стали более 40 государств, а также Европейский союз.

В качестве Приложения к Заключительному акту Конференции по Европейской Энергетической хартии принят Протокол к Энергетической хартии по вопросам энергетической эффективности и соответствуючим экологическим аспектам. Протокол был открыт для подписания с даты завершения указанной конференции только теми государствами и международными организациями, которые подписали Европейскую Энергетическую хартию (Заключительный документ Гаагской конференции по Европейской энергетической хартии), а также Договор к Энергетической хартии. Основными щелями Протокола определены: «содействие политике в области энергетической эффективности, соответствующей устойчивому развитию», создание рамочных основ, «побуждающих производителей и потребителей использовать энергию с максимальной экономией, эффективно и экологически обоснованно, в особенности путем организации эффективных рынков энергии и полного учета экологических затрат и выгод» (ст. 1). Протоколом предусмотрены, в частности, обязательства каждой договариваюшейся стороны формулировать стратегию и программные цели «повышения энергетической эффективности и тем самым ослабления воздействия на окружаюшую среду» (ст. 5); поошрять «коммерческую торговлю и сотрудничество в области энергетически эффективных и экологически обоснованных технологий, услуг и методов управления, относящихся к энергии» (ст. 7); разрабатывать, выполнять и регулярно обновлять «программы повышения энергетической эффективности» (ст. 8). 
С учетом экономического значения нефтегазовых, угольных и иных природных ресурсов, обеспечиваюших энергетику, и растущего сотрудничества государств в этой области в юридической литературе говорится о начале формирования международного энергетического (или природоресурсного) права в качестве подотрасли международного экономического права, хотя договорно-правовых подтверждений в пользу такого подхода в настояшее время пока нет.

Не следует вместе с тем и переоценивать значение этого Договора: еще до согласования текста Энергетической хартии и Договора к ней повсеместно признавалось, что международное право предоставляет сбалансированную основу защиты прав государств на их природные ресурсы, с одной стороны, и, с другой, стандарты стабильности условий международных инвестиций в недропользование, отличающееся особой капиталоемкостью и инерционностью окупаемости во времени ${ }^{6}$. Этот международно-правовой баланс особенно важен для развивающихся стран, в экономике которых доминируют иностранные компании. Исходные применимые положения предоставляют некоторые резолюции Генеральной Ассамблеей ООН, прежде всего 626 (VII) «Право свободной эксплуатачии естественных богатств и ресурсов» (1952 г.) и 1803 (XVII) «Неотъемлемый суверенитет над естественными ресурсами» (1962 г.). Согласно последнему документу, «осуществление и укрепление неотъемлемого суверенитета государств над их природными богатствами и ресурсами укрепляет их экономическую независимость», а право «народов и наций на неотъемлемый суверенитет над их естественными богатствами и ресурсами должно осуществляться в интересах их национального развития и благосостояния населения соответствующих государств». Положения международного права о неотьемлемости суверенитета государств над их природными ресурсами имеют значение и для предупреждения новых экономических переделов мира, в Т.ч. под предлогом поиска оружия массового уничтожения или привнесения в другое государство минимальных стандартов демократин?.

Международно-правовые начала неотъемлемости суверенитета государств над их природными ресурсами реализуются, в т.ч. на реги-

${ }^{6}$ См. об этом подробнее, например, в: Российское горное законодательство. Документы и комментарии / Под ред. В.Ж. Аренса, А.Н. Вылегжанина. М., 1996. С. 5 и далее. ' См. Материалы конференции Дипломатической академии МИД РФ: Круглый стол движения «За укрепление демократического мирового порядка в подлержку ООН». M., 2005. C. 1-62. 
ональном уровне, в рамках конкретных договорных механизмов сотрудничества государств в этой специальной области. Так, по Соглаиению о сотрудничестве государств в области изучения, разведки и использования минерально-сырьевых ресурсов (1997 г.) государстваучастники приняли обязательство «осуществлять мероприятия по развитию геологоразведочных, добывающих и перерабатывающих отраслей», созданию условий для инвестиций в них, по «формированию согласованной политики в области стандартизации и сертификации минерального сырья и продуктов его переработки на базе международно-признанных требований» (ст. 3). Государства-участники договорились «об унификации терминов, применяемых при разведке и использовании минерально-сырьевых ресурсов, на базе международных требований» (ст. 9), а также об обмене «нормативными правовыми документами в области изучения, использования и охраны недр» и принятии мер «по их сближению» (ст. 10). Для осуществления целей Соглашения создан Межправительственный совет, Положение о котором составляет неотьемлемую часть Соглашения (ст. 7). В числе задач и функций Совета - формирование, развитие «рынка минерально-сырьевых ресурсов и продуктов их переработки (преобразования)» в рамках Содружества Независимых Государств; создание условий, обеспечивающих рациональное и комплексное использование месторождений полезных ископаемых; осушествление мер по унификации действующих стандартов, совершенствованию методических документов, «включая классификации и балансы запасов полезных ископаемых» (П. II Положения).

Что касается международно-правовой стабильности условий инвестиций в недропользование, то, согласно указанной резолюции ГА ООН 1962 г., на разведку и эксплуатацию природных ресурсов, так же как и на ввоз требуемого для этих целей иностранного капитала, требуется разрешение. «В случае предоставления разрешения использование ввезенного капитала и доходов с этого капитала регулируется условиями этого разрешения, действующими национальными законами и международным правом». Важное положение этой резолюции о международных гарантиях в случае лишения инвестора прав собственности, возникших в связи с природопользованием: «Национализация, экспроприация или реквизиция должны основываться на соображениях или мотивах обшественной пользы, безопасности или национальных интересов, которые признаются более важными, чем чисто 
личные или частные интересы как граждан, так и иностранцев. В этих случаях владельцу уплачивается соответствующая компенсация согласно правилам, действующим в государстве, которое принимает эти меры в осушествление своего суверенитета, и в соответствии с международным прравом»).

Обязательство уплатить соответствуюшую компенсацию инвестору предусмотрено также и Хартией экономических прав и обязанностей государств, принятой резолюцией Генеральной Ассамблеи ООН (1974 г.). Согласно Хартии, каждое государство имеет право: а) регулировать и контролировать иностранные инвестиции в пределах действия своей национальной юрисдикции; b) регулировать и контролировать в этих пределах деятельность транснациональных корпораций; c) национализировать, экспроприировать или передавать иностранную собственность. В последнем случае государство, принимающее такие меры, должно выплачивать соответствуюшую компенсацию с учетом его применимых законов и постановлений «и всех обязательств, которые это государство считает уместными (and all circumstances that the State considers pertinent)» (п. 2 ст. 2). То есть Хартия, в отличие от приведенной выше резолюции ГА ООН 1962 г, не обязывает национализирующее государство определять размер «соответствующей компенсации» в соответствии с международным правом. Объяснимо поэтому, что западные государства голосовали против этой статьи Хартин. Вместе с тем вряд ли можно утверждать, что на ст. 2 Хартии можно ссылаться как на наличие соответствующей обычной нормы международного права. Напротив, многие развивающиеся страны, голосовавшие за Хартию в ее действуюшей редакции, пошли на заключение таких двусторонних соглашений с западными государствами, в которых предусмотрены их договорные обязательства о защите иностранных инвестиций, в том числе от «политических рисков», с позиций именно международного, а не национального права. Количество действуюших двусторонних договоров государств о защите инвестиций превысило тысячу, и характерным для них является механизм компенсации при изъятии иностранной собственности ${ }^{8}$.

Как показывает международная арбитражная практика разрешений межгосударственных споров по размеру такой компенсации, суды придерживались в основном следующей позиции: а) согласно обычным

${ }^{8}$ P. Malanczuk. Akehurst's Modern Introduction to International Law. Seventh Revised Edition. London and New York, 1997. P. 236-237. 
нормам международного права требуется рrima facie полная компенсация в случае экспроприации собственности иностранного инвестора; б) бремя доказывания применимости в конкретном случае положения о полной компенсации лежит на истце (а это часто означает существенные временные и финансовые судебные издержки инвестора, если он является истцом); в) с учетом отмеченного, проблему компенсации целесообразнее урегулировать посредством глобального «мирового соглашения» ("global settlement"). Его суть в том, что в случае национализации или экспроприации в каком-то государстве объектов собственности, принадлежавших инвесторам другого государства, не каждый из инвесторов добивается компенсации, а государство их национальности достигает с первым государством, с учетом применимых норм международного права, суммарного соглашения ("lump sum agreement") о компенсации. Хотя при этом фактически предоставляется, как правило, не полная, а частичная компенсация, практика суммарных соглашений придает стабильность международному режиму инвестиций, поскольку какая-то компенсация частному инвестору гарантируется на публично-правовом уровне. Наиболее цитируемыми по этой проблеме считаются судебные решения, вынесенные по спору между США и Ираном о национализации американских инвестиций после исламской революции в Иране 1979 года.

Напомним об этом межгосударственном споре. Исламская революция в Иране сопровождалась рядом негативных для инвесторов, в т.ч. американских, факторов, как-то: развал банковской системы Ирана, замораживание иностранных актов в стране, назначение Ираном управляюших иностранными компаниями, отток американского персонала из Ирана и т.П. После захвата посольства США в Иране и последовавшего замораживания иранских активов в США в 1981 г. в соответствии с Алжирской декларацией был учрежден суд по ираноамериканским взаимным претензиям (Iran-U.S. Claims Tribunal). Стороны согласовали, что Суду подведомственны споры между США и Ираном, а также иски американских лиц к Ирану и иранских лиц к США. Примечательна позиция, занятая Судом по одному из исков компаний США к Ирану. С одной стороны, Суд согласился с истцами в том, что обозначенные события в Иране «существенно препятствовали (seriously hampered)» возможностям американских инвесторов продолжать работы по инвестиционному проекту и в конечном счете даже «парализовали проект (paralyzed the Project)». С другой стороны, 
Суд отметил, что инвесторы в Иране «должны были учитывать риск того, что в данной стране могут проходить забастовки, локауты, волнения, смены экономической и политической системы и даже революция»; что эти риски, когда они «материализуются, не обязательно означают, что затрагиваемые ими права собственности следует считать изъятыми. Сама по себе революция не наделяет инвесторов правами на компенсацию согласно международному праву (A revolution as such does not entitle investors to compensation under international law)»?.

Комплекс норм международного экономического права, регулируюших отношения государств в сфере инвестиций, прежде всего в недропользование, называют иногда международным инвестичионным правом. Последнему посвящено в юридической литературе несколько добротных монографий и учебных пособий ${ }^{10}$. Объективно эта часть международного экономического права также применима к отношениям государств в связи с недропользованием: кто-то из государствкредиторов выдвигает обоснованные или сомнительные претензии; кто-то из государств-должников, наращивающих импорт инвестиций, не способен или не желает выполнять обязательства по ранее заключенным договорам - это реальность, которую необходимо учитывать при планировании инвестиционных проектов, в т.ч. в связи с недропользованием. Взыскание экономических долгов государств с помощью вооруженной силы вне рамок Устава ООН запрешено современным международным правом, соответственно оно и в этом плане является безальтернативным регулятором отношений между государством-инвестором и государством, принимающим инвестиции.

Поскольку инвестиции обшепринято считать элементом содействия экономическому благосостоянию государства, объективно оно заинтересовано в обеспечении свободного доступа инвестиций на его территорию. Для этого, как показала практика, недостаточно только национального законодательства о недропользовании, поошряюшего инвестиции. Инвесторов больше привлекает сочетание такого законодательства с благоприятными и применимыми к государству - импортеру инвестиций международно-правовыми актами. В международном

${ }^{9}$ Судебное решение цитируется по: M. Dixon, R. Mc Corquodale. Cases and Materials on International Law. 4th Edition. Oxford. 2003. P. 440-441.

${ }^{10}$ Богатырев А.Г. Инвестиционное право. М., 1992. Юмашев Ю.М. Правовое регулированне прямых иностранных капиталовложений в ЕЭС. М., 1998. Кувшинов В.А. Правовое регулирование иностранных инвестиций в Российской Федерации. М., 2000. Лабин Д.К. Международно-правовое регулирование иностранных инвестиций. М., 2001. 
плане поощряются в большей степени не краткосрочные капиталовложения, а прямые инвестиции. В связи с этим важно определение последних с позиций международного права. Согласно Кодексу либерализачии движения капиталов, принятому ОЭСР в 1961 г., а также европейским актам (например, директиве 88-361 от 24 июня 1988 года о применении ст. 67 и 70 Римского договора), капиталовложение, характеризуюшееся комбинацией следующих признаков, можно квалифицировать как прямую инвестицию: фактически имеет место некий вклад; этот вклад выражен в форме капитала; этот вклад способствует установлению между инвестором и инвестируемым предприятием долговременных связей; эти связи позволяют инвестору оказывать реальное влияние на управление инвестируемым им предприятием".

Конвенцией об учреждении многостороннего агентства по гарантиям инвестиций (Сеульской конвенцией) 1985 г. в основном отмечены эти же юридические признаки инвестиций: а) без вклада нет инвестиций. Однако вклад может быть не только в денежной форме, но и в форме материального вклада (например, оборудования). Взнос в виде предоставления услуг, в том числе интеллектуальных, вкладом не является; б) вклад должен быть сделан на продолжительный период времени; краткосрочные вклады не являются инвестициями; в) инвестор участвует в несении предпринимательского риска, «привязан» к вложению.

Поскольку и некоторые национальные законы, и международные договоры о поошрении и зашите инвестиций предоставляют льготный режим международным (иностранным) инвестициям, возникает вопрос об их юридической идентификации. В соответствии со многими двусторонними договорами о поощрении и защите инвестиций международными считаются те инвестиции, которые осуществляются инвестором - юридическим или физическим лицом одного государстваучастника на территории другого государства-участника. Иной подход к установлению международного характера инвестиций содержат документы Европейского союза и ОЭСР. Согласно им, международными считаются те инвестиции, которые влекут за собой международное (трансграничное) движение капиталов.

В соответствии с Конвенцией об учреждении многостороннего агентства по гарантиям инвестиций (1985 2.) договариваюшиеся госу-

"О значении этого Кодекса см., например: K. Jackson, etc. Legal Problems of Intemational Economic Relations. Cases, Materials and Texts. Third Edition. St. Paul, MINN, 1995. P. 1037. 
дарства, признавая, «что снятие озабоченностей, связанных с риском некоммерческого характера, способствовало бы и еще более содействовало потоку иностранных инвестиций в развивающиеся страны», согласились учредить Многостороннее агентство по гарантиям инвестиций (преамбула, ст. 1 Конвенции). Задача Агентства состоит в том, чтобы «стимулировать поток инвестиций в производственных целях» в экономику государств-участников, «особенно в развивающиеся страны». Конвенцией, в порядке создания благоприятной правовой среды международным инвестициям, предусмотрены гарантии инвесторам на случаи некоммерческих рисков, включая случаи лишения инвесторов права собственности над инвестициями вследствие нового законодательства государства - импортера инвестиций.

Многостороннему агентству по гарантиям инвестиций было предложено разработать общие правовые рамки осуществления иностранных инвестиций. Обсуждение этого вопроса в нескольких международных экономических организациях завершилось в конечном счете разработкой Всемирным банком Руководства (Guidelines) по режиму иностранных инвестиций. Согласно этому документу: политику поощрения каждым государством иностранных инвестиций целесообразно выражать, в частности, в упрощении доступа таких инвестиций и формальностей, с этим связанных; вместе с тем, неоспоримо право каждого государства регламентировать такой доступ; последнее включает в себя и резервирование государством только за своими гражданами возможности заниматься некоторыми видами экономической деятельности (преимущественно затрагивающими национальную безопасность); при доступе иностранных инвесторов рекомендуется не устанавливать для них специальных требований, которые вели бы к искажению конкуренции между иностранными и отечественными инвесторами; при ликвидации или продаже инвестиций рекомендуется разрешать «перевод на родину собственника или трансферт за один раз чистой выручки от указанной ликвидации или продажи, а также от любой причитающейся прибавочной стоимости; в особых случаях, когда у государства недостает иностранной валюты, этот трансферт в виде исключения может осуществляться по частям в максимально короткий срок, не превышающий пяти лет, считая с момента ликвидации или продажи».

То, что значительная часть комплекса международно-правовых норм о недропользовании тяготеет к международному экономическому праву, 
не означает монополии последнего на регулирование отношений государств в этой сфере. Понятно, что в зависимости от конкретного объекта регулирования к таким отношениям применимы, в соответствующих ситуациях, нормы других отраслей международного права: морского (в случае разработок недр континентального шельфа, например); права окружающей среды (практически во всех случаях); космического (в случае разработки недр Луны, к примеру) и т.д. Независимо от сферы недропользования, однако, важнейшим вопросом, требуюшим ответа, является понятийный, а именно: что конкретно означает термин «недра» в международном праве.

Международно-правовое содержание понятия «недра»

Международно-правовой режим недр (в т.ч. недр суши, дна внутренних морских вод, дна архипелажных вод, территориального моря, недр континентального шельфа и т.д.) имеет как общие, так и сущностно различающиеся составляющие.

Большую часть недр Земли составляют морские недра. Очевидна физическая общность морских недр (они находятся не под поверхностью суши, а под морским дном, в океанической земной коре или переходной); и общность международно-правовая (все они - объекты отношений, регулируемых Конвенчией ООН по морскому праву 1982 2.). Кроме естественных различий между недрами в разных регионах, имеются и международно-правовые отличия в международноправовом режиме недр. На одни из них распространяется суверенитет соответствующего государства (недра в пределах сухопутной территории государства; недра дна внутренних морских вод, архипелажных, территориального моря); другие недра имеют иной международноправовой режим - на них распространяются суверенные права прибрежного государства в целях разведки и разработки природных ресурсов (недра континентального шельфа); на третьи - не распространяются ни суверенитет, ни суверенные права государств (недра Антарктики; Международного района морского дна; недра Луны и других планет).

Универсальными международными договорами понятие недр не определено. Согласно глоссарию, выпушенному ООН, термин «недра» (subsoil), использованный в Конвенции ООН по морскому праву 1982 г., означает «всякое естественно наличествуюшее вещество, находящееся ниже дна моря или океана (all naturally occurring matter lying beneath the sea-bed or deep ocean floor)». Недра включают в себя 
«органические отложения и минеральные ресурсы, а также каменное основание под ними (as well as bedrock below)» ${ }^{12}$.

На недра в пределах государственных границ - т.е. в пределах сухопутной территории государства, а также недра дна внутренних морских вод, архипелажных вод, территориального моря - распространяется суверенитет государства. За редкими исключениями, исследователи международного права единодушны в том, что такие недра есть часть государственной территории. Только поверхностью Земли ограничивается понятие «государственная территория» и в шестом издании курса международного права Оппенгейма, подготовленного Лаутерпахтом: «Государственная территория - это та определенная часть поверхности земного шара (definite portion of the surface of the globe), которая подчинена суверенитету государства» ${ }^{13}$. Для обозначения того, что находится под определенной таким образом территорией государства, Оппенгейм пользуется даже термином «территориальные недра» ("the territorial subsoil"), не относя их к компонентам государственной территории $^{14}$. Он пишет, что вопреки частым утверждениям, «территориальные недра» не являются частью территории, но «по универсально признанному правилу права народов недра до неограниченной глубины (the subsoil to an unbounded depth) принадлежат государству, которое владеет территорией над ними» (belongs to the State which owns the territory on the surface) $)^{15}$. Однако такая двусмысленность (недра не часть территории государства, но они «принадлежат» ему) лишь запутывает вопрос. Если согласиться с Оппенгеймом в том, что недра в пределах, обозначенных государственными границами, не являются частью территории соответствующего государства, то возникает вопрос о международно-правовом статусе недр. Сама постановка такого вопроса в условиях широкой реализации суверенитета многих государств над своими недрами имела бы негативные последствия для международно-правовой определенности, стабильности в мире в целом. Указанные недра, конечно же, являются частью государственной территории. Соответственно на этой части территории реализуется

${ }^{12}$ UN Office for Ocean Affairs and The Law of the Sea, Baselines: an Examination of the Relevant Provisions of the United Nations Convention on the Law of the Sea, Appendix I: Glossary of Technical Terms. P. 47, 64.

"International Law. A Treatise. By L. Oppenheim. Vol. 1 - Peace. Sixth Edition. Ed. by H. Lauterpacht. Longmans, Green and Co. London. New York. Toronto. 1947. P. 407.

${ }^{14}$ Ibid. P. 418.

is Ibid. P. 417. 
верховенство государства и самостоятельность в международных отношениях как признаки суверенитета ${ }^{16}$. При этом стержневым элементом суверенитета является именно территориальное верховенство (территориальный суверенитет), т.е. верховенство власти государства по всему пространству, составляющему его государственную территорию ${ }^{17}$. Поэтому передача (юридическому, физическому) лицу территориального верховенства - в т.ч. в отношении недр - это юридический абсурд; недра как и иная часть государственной территории может лишь стать территорией другого государства; но не изъята из территориального суверенитета вообще. Это важно подчеркнуть в контексте дискуссии между иерархами отечественной цивилистики и специалистами по российскому горному праву ${ }^{18}$.

Оценивая значение территориального суверенитета, Международный Суд ООН в деле о проливе Корфу (Великобритания против Албании) отметил: "Between independent States, respect for territorial sovereignty is an essential foundation of international relations"19. На поверхности Земли, в горизонтальном измерении, пределом действия территориального суверенитета являются государственные границы. Как сказано в Законе «О государственной границе Российской Федерации» (№ 4730-I от 1 апреля 1993 года, с посл. изм.), государственная граница определяет «пространственный предел действия государственного суверенитета», однако этот предел определен только как «линия и проходящая по этой линии вертикальная поверхность» (ст. 1), но не горизонтальные поверхности над воздушной территорией России или в подземном пространстве. Иначе говоря, согласно Закону, пространственный предел действия суверенитета России определен не во всех измерениях.

Высотный предел территориального суверенитета (т.е. предел его распространения по вертикали ввысь) определяется в доктрине разде-

${ }^{16}$ См.: подробнее: Ушаков Н.А. Суверенитет в современном международном праве. М., 1963. С. 6-30; Международное право. Отв. ред. Ю.М. Колосов, В.И. Кузнецов. М., 1998. С. 57; Международное право. Отв. ред. Ю.М. Колосов, Э.С. Кривчикова. М., 2000. С. 66: Ушаков Н.А. Международное право. М., 2000. С. 73-74.

${ }^{17}$ Барсегов Ю.Г. Территория в международном праве. М., 1958. С. 26.

${ }^{18}$ С. .6 этом: Клюкин Б.Д. О развитии договорной основы права пользования недрами // Государство и право. № 9. 2004. С. 46-54.

19 «Одной из сушественных основ международных отношений между независимыми государствами является уважение территориального суверенитета». Corfu Channel case, Judgment of April 9th, 1949. I.C.J. Reports 1949. Р. 35. Официальными языками Суда, согласно п. 1 ст. 39 его Статута, являются английский и французский. 
лом между воздушной территорией государства и космическим пространством ${ }^{20}$. Что же касается пределов распространения территориального суверенитета в глубь Земли, то по этому вопросу, не решенному в международно-договорном порядке, в судебной практике и доктрине высказаны разные мнения. В ряде публикаций эти мнения, с учетом базовых данных геологии и других естественных наук о структуре Земли и геосфер, обобщены ${ }^{21}$.

Вкратце они сводятся к следующим подходам: 1) глубина недр «теоретически распространяется до центра Земли» ${ }^{22}$. Сходная позиция: «Геометрически подземную государственную территорию можно представить как сегмент с вершиной в центре земного шара и основанием в виде всей сухопутной и водной территории данного государства» ${ }^{23}$. (Слово «сегмент» здесь использовано неудачно: сегмент - это часть круга, а не часть шара или эллипсоида; автор имел в виду, конечно, конусообразную часть земного эллипсоида с вершиной в центре Земли и основанием на ее поверхности, обозначенным государственными границами данной страны); 2) «Государственное пространство простирается в недра земли на технически доступную глубину ${ }^{24}$; 3) выработалась обычно-правая норма, содержание которой сводится «к применению принципа частного права cujus est solum est usque ad caelum et ad inferos («чья земля, тому принадлежат воздушное пространство и недра»)» ${ }^{25}$; 4) «Недра, находящиеся под сухопутной и водной поверхностями государств, не имеют ни в международном, ни в национальном праве каких-либо ограничений по глубине» ${ }^{26}$. Сходная позиция: «Находящиеся под сухопутной и водной территорией государства

${ }^{20}$ Жуков Г.П. Космическое право. М., 1966. С. 271-293. Международное космическое право. Отв. ред. Г.П. Жуков, Ю.М. Колосов. М., 1999. С. 55, 58-60.

${ }_{21}^{1}$ Вылегжанин А.Н. Подземный предел распространения суверенитета государства // Государство и право. 2001. № 8. Его же: Морские природные ресурсы (международно-правовой режим). М., 2001.

22 Лукашук И.И. Международное право. Особенная часть. М., 1997. С. 5.

2 Клименко Б.М. Границы - проблема мира. М., 1964. С. 13.

${ }^{24}$ Клименко Б.М., Ушаков Н.А. Нерушимость границ-условие международного мира. М., 1975. С. 16.

2s Броунли Я. Международное право. Книга первая. Пер. с англ. С.Н. Андрианова / Под ред. Г.И. Тункина. М., 1977. С. 190-191. Латинский текст указанного выражения и его русский перевод Е.И. Темнов дает в несколько иной редакции. Латинские юридические изречения. Сост. Е.И. Темнов. М., 1996. С. 116.

${ }_{26}^{6}$ Малеев Ю.Н. Территория в международном праве / В кн.: Международное право. M., 2000. C. 114. 
недра также входят в состав его территории без каких-либо ограничений по глубине ${ }^{27}$.

Учитывая авторитет и известность ученых - сторонников мнения о безграничности недр, отметим, почему с этим мнением не представляется возможным согласиться. На недра в пределах государственных границ, обозначенных лишь на поверхности Земли, распространяется суверенитет соответствующего государства, а его действие не может быть безгранично в подземном пространстве. Если согласиться с мнением о том, что недра не имеют ограничений по глубине, то придется признать, что и суверенитет государства распространяется в глубь Земли без ограничений. Но ошибочность такого подхода очевидна: протяженность суверенитета государства в глубины Земли не беспредельна, его суверенитет не может быть распространен, например, через центр Земли на поверхность с противоположной стороны планеты: такое распространение могло быть направлено против территориальной целостности и неприкосновенности другого государства, а это противоречит международному праву (в т.ч. ст. 2 Устава ООН). Следовательно, согласно международному праву недра, на которые распространяется суверенитет государства, всегда имеют ограничения по глубине. Вопрос заключается лишь в том, на какой глубине, в соответствии с современным международным правом, проходит подземный предел действия государственного суверенитета. Подходы к этому законодателей России и США, например, различаются.

В российском законе «О недрах» определено, что недра - это «часть земной коры», расположенная ниже почвенного слоя, а при ее отсутствии - ниже поверхности и дна водоемов и водотоков, простирающаяся «до глубин, доступных для геологического изучения и освоения». То есть российский законодатель не считает, что недра безграничны; по его мнению, недра не распространяются до центра Земли, а ограничиваются только одной из трех ее сфер - земной корой; для правового ограничения глубины недр в земной коре законодатель пользуется критерием доступности для изучения и освоения. В двухтомном российском энциклопедическом словаре говорится о понятии «недра» в двух смыслах. В широком смысле недра Земли «простираются от ее поверхности до центра и включают земную кору, мантию Земли и ее ядро», а «в узком смысле под недрами понимают верхнюю часть земной коры,

${ }^{7}$ Курс международного права. В 7 т. Т. 3. Основные институты международного права. Отв. ред. тома Н.А. Ушаков. М., 1990. С. 9. 
в пределах которой возможна добыча полезных ископаемых» ${ }^{28}$. С этих позиций в российском законе «О недрах» термин «недра» используется в узком смысле. Развивая такое определение российским законодателем термина «недра», Б.Д. Клюкин пишет: «Эта часть природной среды при выделении в горизонтальной плоскости определяется в границах, соответствующих соизмеримой над участком недр поверхности земельного участка, а по глубине определяется верхними и нижними показателями проникновения в глубь земли» ${ }^{29}$. Заметим, что такие показатели с развитием науки и техники меняются, как подобные показатели менялись и в случае с критерием «эксплуатабельности», установленным ранее Конвенцией о континентальном шельфе 1958 г. для целей определения его внешней границы ${ }^{30}$.

Надо учитывать и то, что критерий доступности для геологического изучения и освоения как мерило глубины распространения суверенитета государства над его недрами в пределах государственной территории не сформулирован в Конвенции ООН по морскому праву 1982 г. В 5-томном Комментарии к ней, составленном международным коллективом правоведов, отмечено, что ст. 2 Конвенции 1982 г. (которая, в'частности, предусматривает суверенитет прибрежного государства над недрами дна территориального моря) «отражает известный афоризм: территориальный суверенитет распространяется usque ad caelum, usque ad infernos» ${ }^{31}$. Где конкретно находятся эти «безжизненные глубины», комментаторы не указывают.

${ }^{28}$ Российский энциклопедический словарь. Книга 2. Гл. ред. А.М. Прохоров. М., 2000. C. 1034.

${ }^{29}$ Клюкин Б.Д. Статья «Недра». В кн.: Андреева Е.Е., Аренс В.Ж., Барсегов Ю.Г. и др. Горное дело и окружающая среда: мировой опыт правовой гармонизации. Словарь. М., 2000. С. 265-266.

${ }^{30}$ Согласно этой Конвенции, суверенные права прибрежного государства на континентальный шельф распространяются на поверхность и недра дна подводных районов, примыкающих к побережью этого государства, за пределы его территориального моря «до глубины 200 метров или за этим пределом, до такого места, до которого глубина покрывающих вод позволяет разработку естественных богатств зтих районов». Статья 1 Конвеншии о континентальном шельфе от 29 апреля 1958 г. Подробнее о критерии эксплуатабельности см.: Калинкин Г.Ф. Режим морских пространств. М., 1981. С. 134-167. Составители Конвенции ООН по морскому праву 1982 г., определив по-иному внешнюю границу континентального шельфа, отказались от критерия экслуатабельности (ст. 76 Конвенции 1982 г.). См. подробнее: Вылегжанин А.Н., Гуреев С.А., Иванов Г.Г. Международное морское право. М., 2003.

31 «Так высоко, как небо, и так глубоко, как безжизненные глубины» (лат.). United Nations Convention on the Law of the Sea. 1982. A Commentary. Vol. II. P. 52. 
Как пишет М. Клаусон, в прошлом директор Бюро управления ресурсами земли Министерства природных ресурсов США, законодательство США восприняло принцип, по которому право собственности на земельный участок распространялось «от центра Земли до зенита небесной сферы» ${ }^{32}$. На этот же «применимый правовой принцип» указывает в фундаментальном исследовании «Право окружающей среды. От ресурсов до восстановления» и американский правовед С. Кэмпбелл-Монн при характеристике ею соотношения прав на земельный участок и ресурсы нефти в недрах под ним: «По применимому правовому принципу ad caelum, собственник поверхности земельного участка владел всеми правами (owned all rights) от неба до ядра земли (from the heavens to the core of the earth)» ${ }^{33}$. Вопреки распространенной среди отечественных цивилистов точке зрения, в американской правовой системе права лица на земельный участок (и на недра) не абсолютизируются, не поднимаются до публично-правового уровня: проводится различие между вешно-правовым институтом собственности на земельный участок и суверенитетом государства над территорией: в отношении земельной собственности частных лиц соответствуюший штат осуществляет на публично-правовом уровне юрисдикцию и контроль (jurisdiction and control), такой объект частной собственности независимо от смены собственника - входит в территорию штата (territory of a state), а последняя составляет часть государственной территории CША (territory of the U.S.), находящуюся под суверенитетом ${ }^{34}$. То есть юридически невозможно изъять из суверенитета США какойлибо участок недр в пределах государственных границ США. В отношении последнего совпадают позиции законодателя России и США. Но в отличие от российского закона «О недрах», американский закон не ограничивает протяженность недр по глубине: ни лишь одной геосферой (земной корой); ни доступностью их для геологического изучения и освоения.

Обозначение (американскими комментаторами законодательства) подземного суверенитета государства центром земного сфероида внешне выглядит привлекательным своей определенностью. Вместе с тем при таком решении вопроса всеми государствами мира верховенство

\footnotetext{
:Clawson M. Uncle Sam's Acres. Westport. 1970. P. 75.

$\because$ Environmental Law. From Resources to Recovery. Ed. Celia Campbell - Mohn. West Publishing Co. St. Paul, Minn, 1993. P. 700.

"B Black's Law Dictionary. Sixth Edition. St. Pane, MINN. West Publishing Co. 1990. P. 1473.
} 
власти каждого из них было бы распространено на те ключевые компоненты Земли, от которых зависит функционирование самой планеты, т.е. внутреннее и внешнее ядро, мантию Земли. Дело даже не в том, что реализовать это право сегодня государства не могут. Важнее другое. Данные тектоники и других отраслей геологии показывают, что развитие земной коры и иных геосфер не прекращается, они постоянно эволюционируют; в предотвращении вредного воздействия какого-то одного государства (или организации, лица и т.д.) на эти эволюционные процессы объективно заинтересованы все государства. Принимая во внимание практически непредсказуемые возможности развития современных естественных наук, горных и военных технологий, распространение верховенства власти всякого государства до центра Земли без упреждающей международно-правовой регламентации вряд ли отвечало бы заинтересованности международного сообщества в глобальной безопасности, сохранении нашей планеты.

Далее, согласно законодательству США о природных ресурсах, в частности о разработке металлосодержащих руд, «недра» - это все, что находится глубже растительного слоя поверхности Земли ("the surface vegetation") и почвы ("soil") 35. Семантически такому же значению соответствуют английский ("subsoil") и французский (sous-sol) эквиваленты русского слова «недра», которые используются в ряде международных договоров, в т.ч. в Конвенции ООН по морскому праву (ст. 2, 34, 49 и др.) и которые на русский язык дословно переводятся как «под почвой», «ниже почвы».

Вместе с тем положения законодательства США, не устанавливая юридический предел прав лиц на недра в глубине Земли и не ограничивая такие права лишь земной корой, предусматривает механизм получения государственной властью информачии о фактической глубине ресурсных разработок. Так, законодательство обязывает, например, разработчиков нефти предоставлять в Службу управления минеральными ресурсами планы производства и развития (production and development plans) нефти и в этих планах обязательно указывать глубину нефтяных разработок, причем в отношении каждой из планируемых скважин ("of each proposed well")

Данные геологии, иных естественных наук свидетельствуют: для образования минеральных ресурсов значение имеют в первую очередь

${ }^{35}$ Environmental Law. From Resources to Recovery. P. 772.

${ }^{36}$ Ibid. P. 736-737. 
процессы в земной коре и в верхней мантии Земли. Сами же минеральные ресурсы находятся не в мантии Земли, и тем более не в ядре Земли, а в земной коре, материковой, океанической, промежуточной ${ }^{37}$. Непосредственные «природоресурсные» интересы государств главный побудительный мотив создания правовых норм о недрах на данном этапе развития цивилизации не простираются ниже границы между земной корой и мантией (хотя известны случаи бурения в научных целях на глубинах, превышающих минимальную толщину земной коры).

Правовой режим недр в пределах государственной территории не следует смешивать с режимом недр за такими пределами. Первые составляют часть территории государства и находятся под его суверенитетом. Вторые - т.е. недра за пределами государственной территории, прежде всего морские недра за пределами дна территориального моря, - не находятся под суверенитетом государства. Такие недра, согласно Конвенции ООН по морскому праву 1982 г., подразделяются на: а) те, которые составляют вместе с поверхностью морского дна за пределами территориального моря континентальный шельф прибрежного государства; и б) те недра, которые составляют вместе с поверхностью морского дна за пределами национальной юрисдикции Международный район морского дна, обозначенный в Конвенции 1982 г. термином «Район». Над континентальным шельфом, в т.ч. и над его недрами, прибрежное государство осуществляет суверенные права в целях его разведки и разработки его природных ресурсов (п. 1 ст. 77 Конвенции 1982 г.). Суверенные ресурсные права прибрежного государства не распространяются на Район; деятельность в нем государств и иных субъектов международного права регулируется только в связи с разведкой и разработкой природных ресурсов Района (п. 1 ст. 1 Конвенции 1982 г.) - как на поверхности морского дна, так и в недрах. Согласно Конвенции 1982 г., именно разведка и разработка природных ресурсов является допустимой и регулируемой деятельностью государств в том подземном пространстве, которое обозначено термином «недра» - и в пределах континентапьного шельфа, и в пределах Района. Ничто в Конвенции 1982 г. не позволяет утверждать, что воля заключивших ее государств состояла в расширительном понимании понятия «недра», используемого в конвенционных Частях VI

${ }^{37}$ Горная энциклопедия в пяти томах. Гл. ред. Е.А. Козловский. Том 2. М., 1986. С. 371 374; Том. 3. М., 1987. С. 409 и далее. 
и XI - как охватывающего, например, и те пространства в глубине нашей планеты, в которых невозможна разведка и разработка природных ресурсов. Изложенное позволило сделать еше в 2001 г. весьма ответственный в международно-правовом плане вывод: и «недра» как часть континентального шельфа, и «недра» как часть Района по смыслу Конвенции 1982 г. не простираются в глубь Земли ниже предела реализации природоресурсных интересов государств, т.е. на современном этапе развития науки и техники ниже земной коры. Мантийное вешество, внешнее и внутреннее ядро Земли - это уже не «недра» Района или континентального шельфа ${ }^{38}$.

Протяженность суверенитета над недрами в пределах государственной территории вглубь не должна юридически зависеть от того, отмеряется ли эта глубина от района суши или от района морского дна; иными словами, должен быть концептуально единый для земной коры правовой предел действия суверенитета в подземном пространстве - и от материковой коры (сухопутные части территории государства), и от океанической коры или промежуточной (дно его внутренних морских вод, территориального моря, а также дно архипелажных вод).

Не следует считать пробелом в международном праве и режим недр в Антарктике: он определяется системой Договора об Антарктике 1959 г. ${ }^{39}$. Равным образом международно-правовые особенности Арктики (в том числе исторически сложившаяся практика национального регулирования арктическими государствами деятельности в регионе) несомненно следует учитывать при определении правового режима недр Арктики ${ }^{40}$. Наконец, при всей дискуссионности вопроса о правах трех новых прикаспийских государств (Азербайджана, Туркменистана, Казахстана) на Каспий ${ }^{41}$, не вытекающих из доктрины uti possidetis, не подтвержденных российско-персидским договором 1921 r. $^{42}$, очевидно одно: сообразно современной воле России, Ирана

${ }^{38}$ См.: Морские природные ресурсы (международно-правовой режим). С. 123-124.

${ }^{39}$ См.: Голицын В.В. Антарктика: тенденции развития режима. М., 1989; Лунин В.В., Клоков В.Д., Помелов В.Н. Система Договора об Антарктике. Правовые акты, комментарии. С-Петербург, 2002.

${ }^{40}$ Вылегжанин А.Н., Гуреев С.А., Иванов Г.Г. Международное морское право. М., 2003.

"' Барсегов Ю.Г. Каспий в международном праве и мировой политике. М., 1998.

${ }^{42}$ A. Vylegjanin. Basic Legal Issues of the Management of Natural Resources of the Caspian Sea. In: The Caspian Sea: a Quest for Environmental Security. Ed. W. Ascher and N. Mirovitskaya. Kluwer Academic Publishers. Dordrecht/Boston/London, 2000. P. 163-172. 
и новых прикаспийских государств будет завершено формирование международно-правового режима недр дна Каспия ${ }^{43}$.

Итак, для решения вопроса о международно-правовом измерении недр, находящихся под суверенитетом государства, возможны, как показала законодательная практика России и США, два альтернативных измерения: 1) пространственное - до центра Земли; или 2) ресурсное или «эксплуатабельное» - до глубин, доступных для геологического изучения и освоения природных ресурсов. Во втором случае «освоение», понятно, не сводится к использованию лишь минеральных ресурсов (достаточно напомнить, например, о перспективности геотермальных ресурсов). Кроме того, этот вариант юридического измерения глубины недр ориентирует на то, что по мере развития науки и техники будет отодвигаться вглубь и подземный предел действия государственного суверенитета.

Возможно теоретически и третье международно-правовое решение: например, действие суверенитета государства ограничивается в глубине Земли каким-то признанным пределом. Ниже его не регламентируемая специальными нормами международного права подземная деятельность государства значительно повышает риск негативных ее последствий для естественной эволюции геосистем, в том числе в связи с процессами движения литосферных плит, вулканических извержений и землетрясений; соответственно резко возрастает риск нанесения ущерба безопасности других государств, угроза самому существованию планеты. Судя по нынешним естественно-научным данным, таким «неполитизированным» подземным пределом относительно безопасного действия суверенитета государства могла бы стать граница между земной корой и мантией, в т.ч. определяемая, например, как известная «поверхность Мохоровичича» ${ }^{44}$.

Исходя из изложенного, в контексте de lege ferenda можно прогнозировать, что в будушем в первую очередь предстоит согласовывать специальный правовой режим деятельности государств в океанической земной коре.

Изложенное, вместе с тем, не означает, что в настояшее время.земная кора, иные геосферы Земли предоставляют правовой вакуум.

4; Вылегжанин А.Н., Андреева Е.Е., Сперанская Л.В. К учету международно-правовых начал экосистемного управления природными ресурсами Каспия // Вестник Каспия. 2002. № 6. С. 68-76.

${ }^{44}$ Подробнее см.: Вылегжанин А.Н., Гуреев С.А., Иванов Г.Г. Цит. соч. 
К уже охарактеризованным применимым документам добавим, что согласно Конвениии по изменению климата 1992 2. геосферы наряду с атмосферой, гидросферой и биосферой определены в качестве компонента климатической системы (п. 3 ст. 1 Конвенции), а участники Конвенции приняли обязательство «защищать климатическую систему на благо нынешнего и будущих поколений человечества» (п. 1 ст. 3).

Вообще принципы и нормы международного экологического права будут в перспективе все более предметно и повсеместно регулировать отношения, связанные с недропользованием. Это направление исследований, думается, весьма перспективно и для отечественной правовой науки. В рамках данной статьи ограничимся лишь напоминанием о некоторых исходных констатациях. Сохранение «экологического баланса в общепланетарном значении» отнесено наукой к тем глобальным проблемам, «неконтролируемое развитие которых может привести к катастрофическим для всей планеты последствиям ${ }^{45}$. В документах Конференции по окружающей среде и развитию 19922. подчеркнута фундаментальная роль Мирового океана (в т.ч. его дна) в сохранении теплового баланса планеты и ее биоразнообразия. В соответствии с Конвенцией о биологическом разнообразии 1992 2. стороны признали большое значение «биологического разнообразия для эволюции и сохранения поддерживающих жизнь систем биосферы» и договорились, в частности, сотрудничать по «вопросам, представляющим взаимный интерес, в целях сохранения и устойчивого использования биологического разнообразия» (Преамбула и ст. 5 Конвенции). В Европейской конвенчии о заичте окружающей среды средствами уголовного права 1998 г. говорится, что «неконтролируемое использование технических средств и чрезмерная эксплуатация природных ресурсов создают для окружаюшей среды серьезные угрозы, которые могут быть отведены надлежащими и согласованными мерами» (Преамбула Конвенции). Еще важнее подчеркнуть то, что в самой целостности современного миропорядка заложена универсальность регулятивного воздействия международного права; что к нынешней и будущей деятельности государств в подземном пространстве, в т.ч. в земной коре и ниже ее, применимы общепризнанные принципы и нормы международного права.

${ }^{45}$ Тимошенко А.С. Формирование и развитие международного права окружающей среды. М., 1986. С. 3. 
Как уже отмечено в международно-правовой литературе, право может регулировать вмешательство человека в природные процессы ${ }^{46}$, и на самом деле международное право регулирует международные отношения по поводу такого вмешательства. Вопрос о юридическом содержании понятия «недра» в таком контексте является не только вопросом национального законодательства, но и, в первую очередь, международно-правовым. Это важно подчеркнуть и с учетом того, что в настоящее время все глубже в недра земли проникает деятельность государств в целях использования запасов не только «традиционных» минеральных ресурсов, но и глубинного тепла нашей планеты (геотермальные станции в России, США, Японии, некоторых других странах), в медицинских, научных и рекреационных, а также в военных целях. Такая деятельность согласно действующему международному праву не должна наносить ущерба целостности Земли, биоразнообразию нашей планеты, способности ее к самоадаптации, в т.ч. и в связи с растущей антропогенной нагрузкой в подземных пространствах, включая глубокие бурения и подземные взрывы ${ }^{47}$; не должна усиливать глобальные или региональные риски, негативно влиять на естественное функционирование геосфер. Это естественное функционирование - одно из обязательных компонентов безопасности планеты Земля, а такая безопасность неделима. Она, как известно, всеобщая по сути, ее невозможно обеспечить на отдельно взятой территории государства. Техногенная катастрофа под поверхностью Земли может свести на нет дорогостояшие усилия государств по поддержанию безопасности в мире, обеспечиваемую в числе других факторов и таким важнейшим, как международное право. А ведь техногенные последствия бурений, иных «вторжений» в земную кору, например, пока не оценены в полной мере (неясно, наличествует ли причинно-следственная связь между такой деятельностью и проседаниями грунта, смещением на территорию другого государства продуктивного нефтегазоносного слоя и т.п.) ${ }^{48}$. Соответственно выкристаллизовывается глобаль-

\footnotetext{
${ }_{46}$ Черниченко С.В. Теория международного права. Том I. М., 1999. С. 111.

47 Что касается ядерных взрывов под землей, то, согласно Договору о всеобъемлюшем запрещении ядерных испытаний 1996 г, государства-участники приняли обязательства «не проводить любой испытательный взрыв ядерного оружия или любой другой ядерный взрыв, а также запретить и предотвращать любой такой ядерный взрыв в любом месте», находящемся под их юрисдикцией или контролем (ст. 1).

48 Такие вопросы поднимались, в частности, в выступлениях специалистов горного дела и экологов на научной конференции «Экологические аспекты энергетической
} 
ная целесообразность во все более детальном и упреждающем международно-правовом регулировании деятельности государств, воздействующей на жизненные компоненты земной коры и иных геосфер.

стратегии как фактор устойчивого развития России» (Москва, 17 октября 2000 г.). Экологические вопросы, как отмечено в международно-правовой науке, «также включаются в сферу международной безопасности» - см.: Международное право и международная безопасность: военная и политическая область. Ред. кол. У.Д. Джексон, Б.М. Клименко, В.И. Кузнецов, М., 1991. С. 13. 